\title{
The UK Financial Sector and EU Integration after Brexit: The Issue of Passporting
}

\author{
Dirk Schoenmaker ${ }^{1}$ \\ Rotterdam School of Management, Erasmus University \\ Bruegel
}

October 2016

\begin{abstract}
If the UK cannot secure a 'Norway' deal and stay within the internal market after Brexit, the UK will lose passporting rights for EU financial services and access to euro clearing and settlement, both of which make London attractive as a financial centre. A substantial part of the UK's wholesale banking and trading sector may move out.
\end{abstract}

\section{The City of London outside the European Economic Area}

Part of London's attractiveness as international financial centre is the access to the internal market of the wider European Economic Area (EEA). By using a UK licence as European passport, foreign financial firms can offer their financial services throughout the EEA. London as financial centre is also home to the vast majority of eurodenominated trading with access to euro-settlement and clearing systems. If the UK cannot secure a "Norway" deal and stay within EEA after Brexit, the UK will lose the passporting rights and access to the euro-settlement and clearing systems.

Analysing the impact on banking and insurance, we find that the insurance industry makes very limited use of the passport in comparison to the banking industry. Next, we analyse the impact on wholesale banking and securities and derivatives trading. The French President, Hollande, has already announced that the City of London should no longer be able to clear euro-denominated trades after Brexit (FT, 2016).

Our findings on wholesale banking and trading are indicative. The early numbers suggest that up to half of the total UK banking system relates to wholesale banking in the City of London. Wholesale banking covers the full remit of trading and derivatives activities and takes place in several currencies (US dollar, euro and pound sterling). Next, we find that, in particular, the OTC derivatives markets might be affected, as 75 percent of euro-denominated OTC interest rate derivatives are traded in London.

\footnotetext{
1 This paper will appear as Chapter 4 in The Economics of the UK-EU Relationship: From the Treaty of Rome to the Brexit Vote, edited by N. Campos and F. Coricelli, Palgrave McMillan, London. The paper draws on two blogposts "Losing "EU passport" would damage City of London" and "Lost passports: a guide to the Brexit fallout for the City of London" published in June 2016 at Bruegel. The author would like to thank Uuree Batsaikhan and Elena Vaccarino for excellent research assistance.
} 


\section{The development of London's position}

London is the wholesale banking hub of the EU. Figure 1 illustrates inward banking from other EU countries and from third countries. Cross-border business from banks headquartered in other EU countries has declined from an all time high of $£ 2.1$ trillion in 2008 to $£ 1.1$ trillion in 2015. While this trend is is line with the general decline in crossborder banking in the EU in the aftermath of the global financial crisis, the decline is more pronounced in the UK. By contrast, cross-border banking from third countries has remained high at $£ 2.2$ trillion throughout this period.

Zooming in on inward banking from third countries, Figure 2 shows that the vast majority of third country banking in the EU takes place in the UK. Only 20 percent is directed towards other EU countries. There is a slight decline of the UK's position from 83 percent in 2003 to 77 percent in 2015. Figure 2 confirms the dominant position of London as the global banking hub of Europe.

In this chapter, we review the possible impact of Brexit on the size of the UK financial sector. Haldane, Brennan and Madouros (2010) provide an interesting discussion on the contribution of the financial sector to the economy: what is the value added of the financial sector and how to measure it.

\section{Figure 1: Development of UK banking sector (in GBP trillions)}

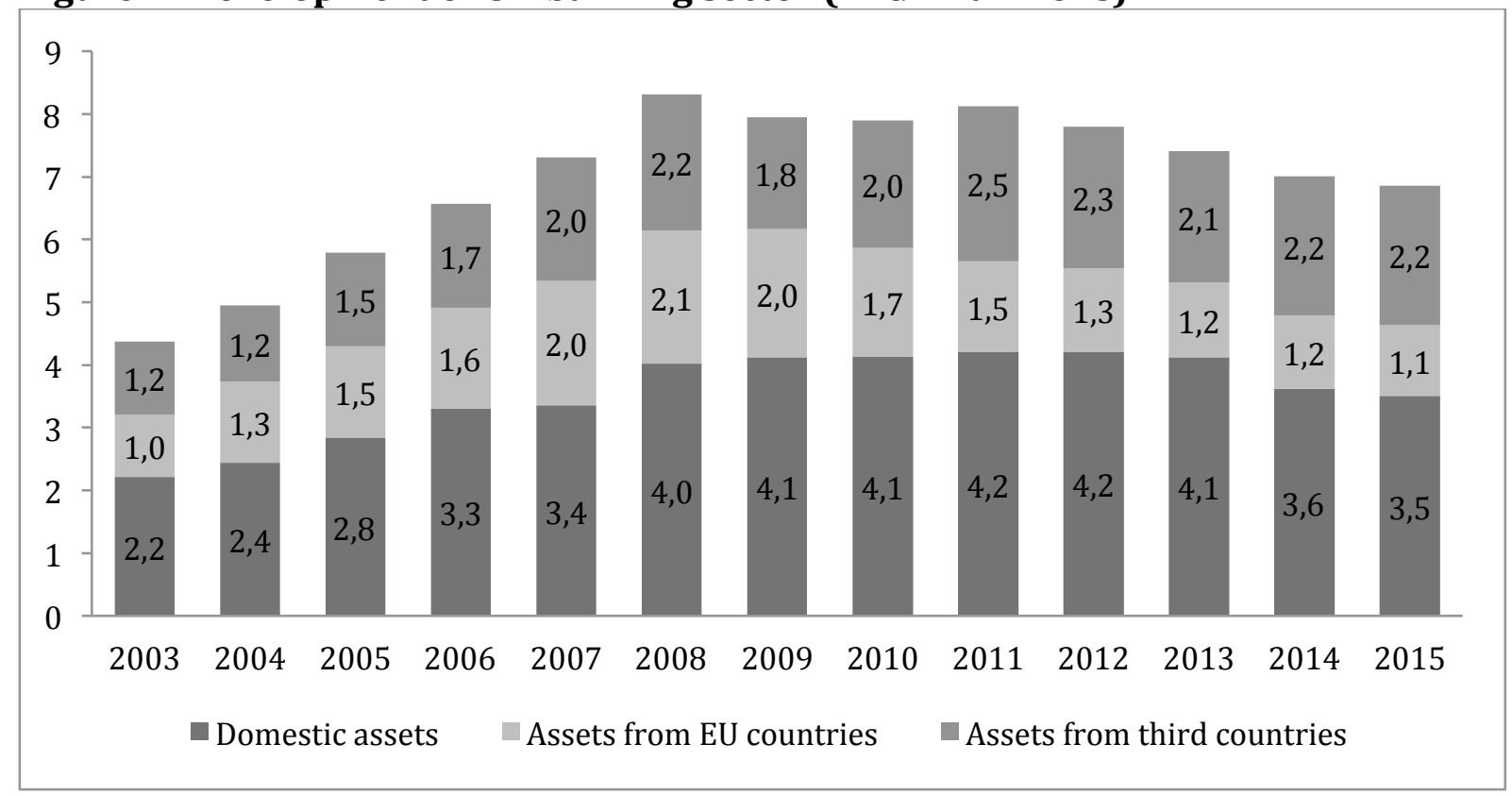

Source: Author calculations based on ECB (2015).

Notes: The assets of the UK banking sector are split in assets of domestic banks, assets of banks from EU countries and assets of banks from third countries. 
Figure 2: Cross-border banking from third countries (share in \%)

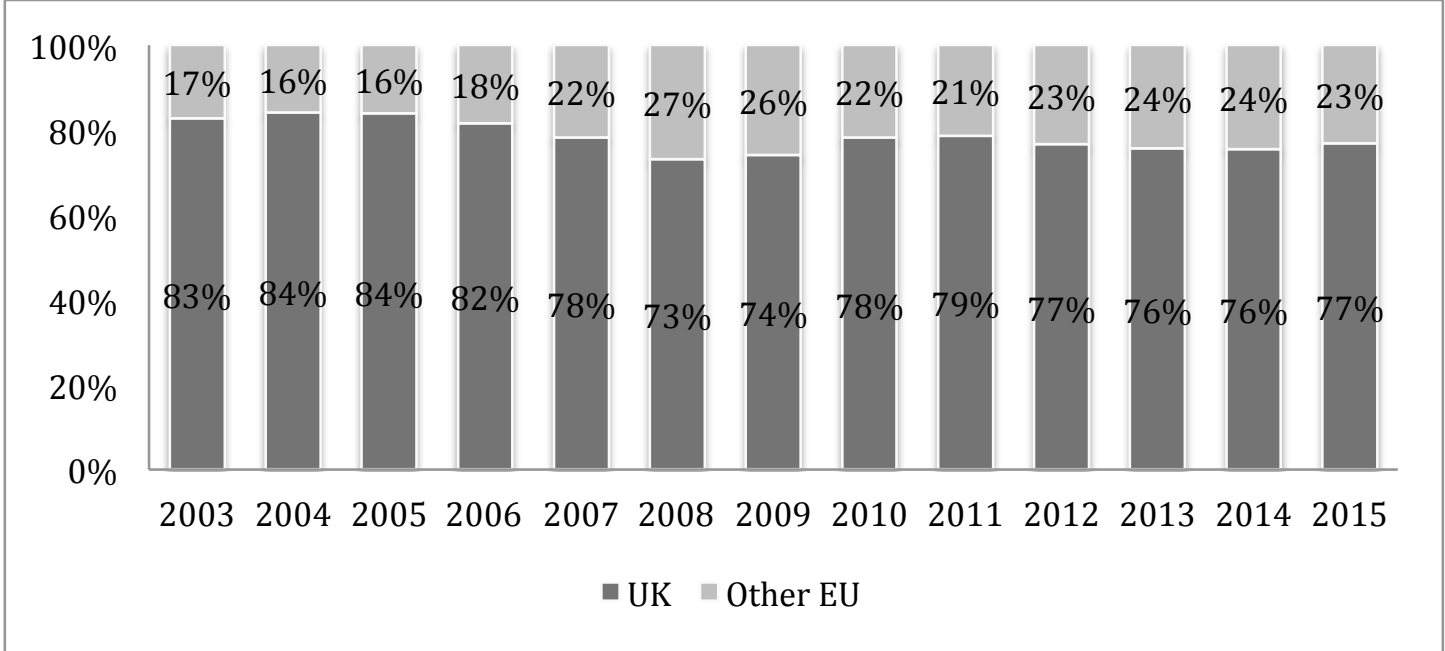

Source: Author calculations based on ECB (2015).

Notes: Total cross-border assets of banks from third countries are broken down in the UK and the rest of the EU.

Moving to the forex market, Figure 3 illustrates the pre-eminent position of London in the foreign exchange (forex) market. This position has even increased from 32 to 37 percent over the 2003-2016 period. Forex turnover in the UK is twice as large as that in the US (19 percent). Figure 4 shows the OTC interest rate derivatives market. While the UK has also been the top global trading hub up to 2013, the US has overtaken the prime position in 2016. This switch mirrors the underlying shift from EUR to USD contracts. The average daily turnover of US dollar contracts rose from $\$ 639$ billion in April 2013 to $\$ 1.4$ trillion in April 2016. By contrast, that of euro-denominated contracts - historically the most actively traded segment - declined from $\$ 1.1$ trillion in April 2013 to $\$ 638$ billion in April 2016 (BIS, 2016). The UK is a major trading hub for euro-denominated contracts (see Section 7 below).

Figure 3: Foreign exchange turnover (\% share of total)

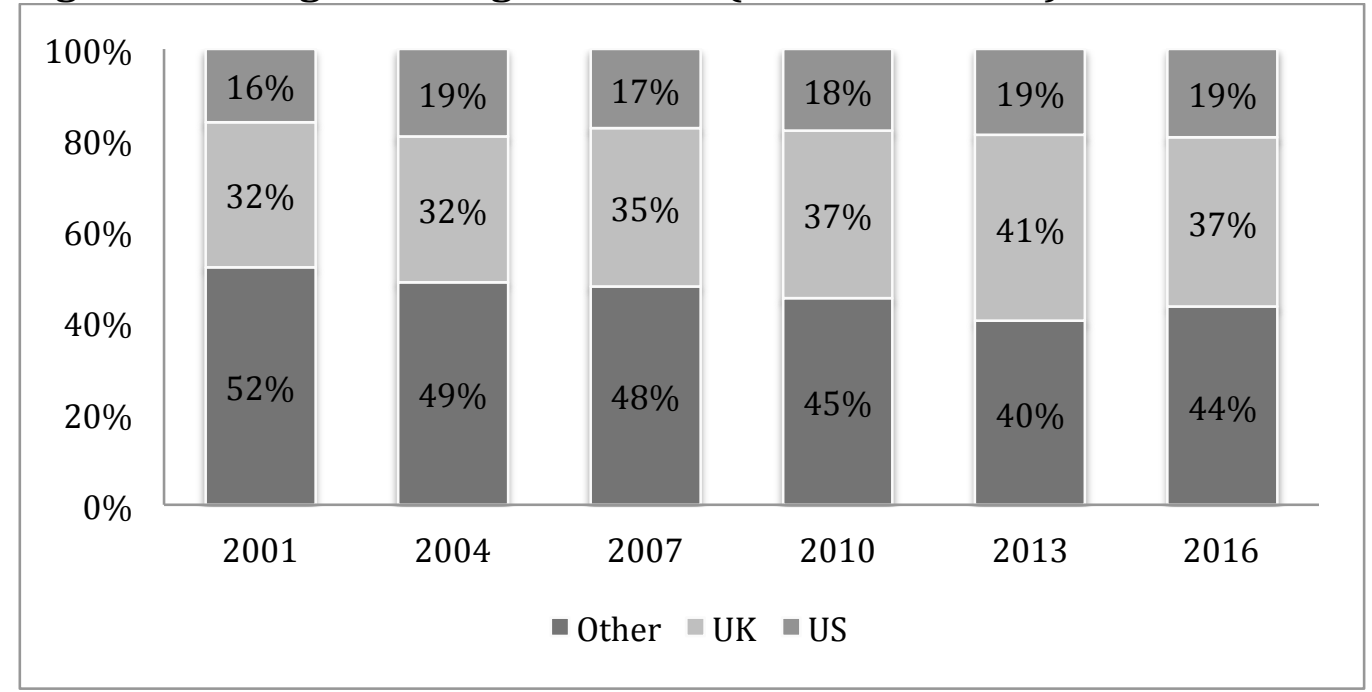

Source: 2016 Triennial Central Bank Survey of Foreign Exchange and OTC Derivatives Markets (BIS, 2016) 
Figure 4: OTC interest rate derivatives turnover (\% share of total)

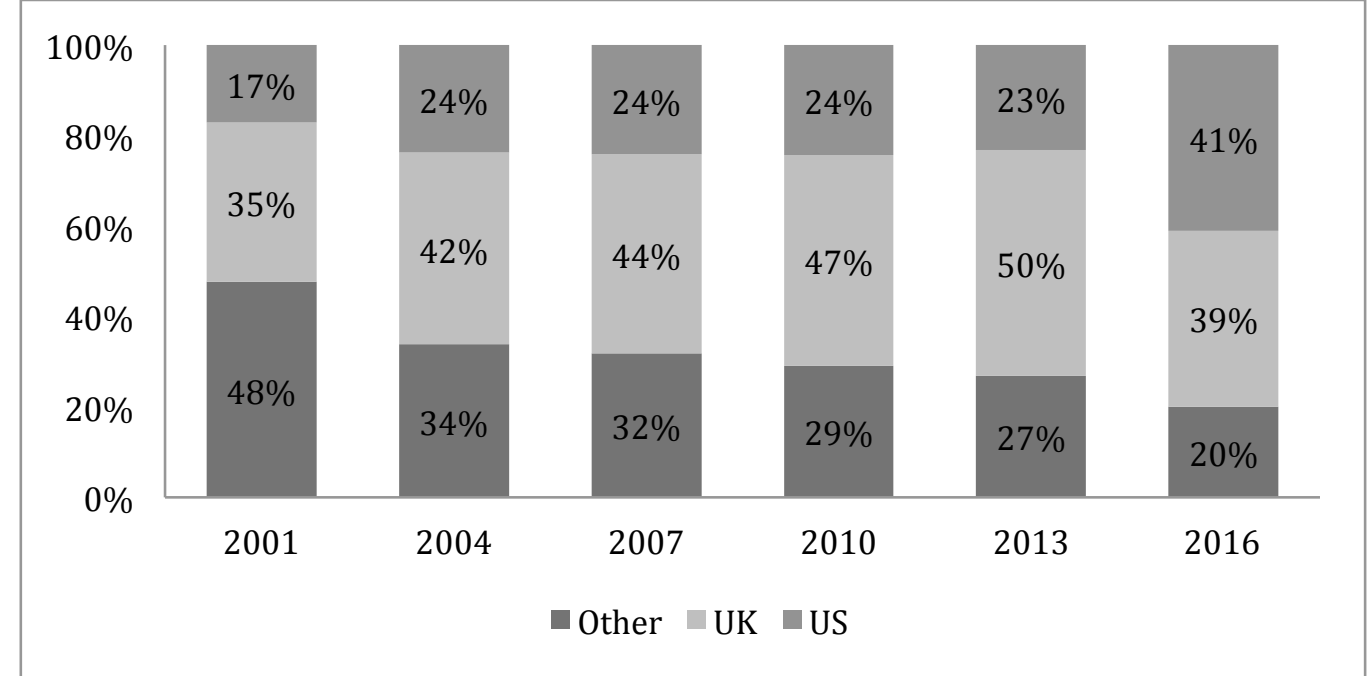

Source: 2016 Triennial Central Bank Survey of Foreign Exchange and OTC Derivatives Markets (BIS, 2016)

\section{The passport}

The internal market is underpinned by a network of Directives and Regulations, which permit access to other EEA member states if a firm has a licence in one member state (the 'home' member state). The most important directives for financial services are:

- the Capital Requirements Directive (CRD IV, 2013/36/EU) for banking

- the Insurance and Reinsurance Directive (Solvency II, 2009/138/EC) for insurance

- the Markets in Financial Instruments Directive (MiFID, 2004/39/EC) for investment services

- the Alternative Investment Fund Managers Directive (AIFMD, 2011/61/EU) for hedge funds and private equity

- the Prospectus Directive (2010/73/EC) for issuing securities

- the Undertakings for the Collective Investment in Transferable Securities Directive (UCITS, 2009/65/EC) for marketing and trading investment funds

We illustrate the how the passport works legally with the Capital Requirements Directive (CRD IV), the legal framework for credit institutions (banks). The passport consist of several elements of the CRD IV:

- Licence: Title III of CRD IV (Articles 8 to 21) specifies the requirements for access to activity of credit institutions. The main element is authorisation by the home supervisor, which provides the single licence.

- Freedom of establishment: Title V (Articles 33-39) contains the provisions concerning the freedom of establishment and the freedom to provide services. It means that if a credit institution is authorised in one member state, it has the freedom to establish a branch in (or to provide services to) any other EEA member state without prior approval. The credit institution only needs to notify the host country supervisor.

- Home supervision: Title VII sets out the principles of prudential supervision, which predominantly gives powers to the home supervisor with some very limited powers for the host supervisor in the area of liquidity supervision. As these powers of liquidity supervision are related to the operations in different 
currencies, the new European Banking Supervision framework has decided to give up these host country powers within the euro area, which uses the single currency (Schoenmaker and Véron, 2016).

This system of full access based on a single passport provided by the home-country supervisor is limited to the EEA. So if the UK were to leave the EEA, UK licenced banks (whether or not headquartered in the UK) would need to obtain an extra licence from the host supervisor in an EEA member state in order to offer financial services in that member state.

An extra licence would be necessary for all forms of cross-border services, ie through the establishment of a branch or subsidiary or through the direct offering of crossborder services. The UK would then become a third country, which would need to find a point of access into the EEA for business. Similarly, EEA financial institutions would need to apply for a licence to enter the UK. The passport system in the other EU financial services directives is similar to the CRD IV.

\section{Banking vs insurance}

An interesting question is whether different financial sectors are equally affected by possible changes in passporting arrangements for the financial sector. We examine the two largest financial sectors, banking and insurance. It appears that banking relies far more on the passport than insurance. We measure this by differentiating cross-border business through branches (based on the passport) and subsidiaries (new licence).

Table 1 reports the relative share of branches and subsidiaries in cross-border business. The passport (branch) is not important for insurance. The aggregate number for all EU member states is 13 percent, and even less for the UK at 9 percent. These are minor amounts. The main vehicle is through subsidiaries, because insurers want to contain 'insurance' risk in separate legal entities. At the aggregate EU level, the relative share of branches is 36 percent for banking.

Finally, European banks typically use their passport to enter the London wholesale market; that is for 69 percent of the cases. Many international banks, including the major European ones, have branches operating in London, which is an international financial centre, but actually do little business with UK clients (Burrows and Low, 2015).

Table 1: Cross-border business by type of entry (2014)

\begin{tabular}{|l|l|c|c|}
\hline \multirow{2}{*}{ EU-wide } & Type of entry & Banking & Insurance \\
\hline \multirow{2}{*}{ United Kingdom } & Branch & $36 \%$ & $13 \%$ \\
\cline { 2 - 4 } & Subsidiary & $64 \%$ & $87 \%$ \\
\cline { 2 - 4 } & Branch & $69 \%$ & $9 \%$ \\
\cline { 2 - 4 } & Subsidiary & $31 \%$ & $91 \%$ \\
\hline
\end{tabular}

Sources: Banking entry data are from ECB (2015) and insurance entry data from Schoenmaker and Sass (2016)

Note: Banks and insurers can enter other member states by branch (no further licence and supervision) or by subsidiary (separate licence and supervision from host country). The table reports the relative share of branches and subsidiaries in cross-border business. The first rows are for all EU member states; the latter rows are for the UK. 
In summary, insurance will be far less affected than banking if and when the UK leaves the EU. Next, the major European banks would need to apply for a UK licence, if they want to keep on doing business in London. In turn, the UK banks would need to apply for a licence in the EEA (see next section).

\section{Wholesale banking}

What is the size of London's wholesale banking activity? Table 2 provides an overview of the total UK banking system. Most UK banking assets ( $£ 3,570$ billion) are held by the major UK international banks: HSBC, RBS, Barclays and Standard Chartered. While Standard Chartered operates primarily in Asia, the first three are active in Europe. HSBC and RBS have already a subsidiary (and thus a licence) on the continent: HSBC in France and RBS in the Netherlands. Barclays operates through branches, for example, in Italy and France (Schoenmaker and Véron, 2016). So, only Barclays might need an extra licence to enter the EEA after Brexit. Based on the banks' annual reports, we estimate that about one third of the total assets of the major UK banks relate to their trading and derivatives books in London, amounting to $£ 1,180$ billion.

The major domestic UK banks and other UK banks have most of their operations in the UK and concentrate on traditional banking business, with little or no trading or derivatives business.

Table 2 shows further that $£ 1,730$ billion in assets in London is held by the major international investment banks, mainly from the US and Switzerland. These US and Swiss investment banks use London as a hub for their European operations (Goodhart and Schoenmaker, 2016). Table 3 indicates that 90 percent of European turnover and employees of the five large US investment banks (Goldman Sachs, JP Morgan, Citigroup, Morgan Stanley, Bank of America Merrill Lynch) are located in London. These investment banks use their UK passports (both the banking licence under CRD IV and investment services licene under MiFID) to conduct business throughout the EEA. These investment banks are currently looking for a new passport in the EEA.

At this stage, it is guesswork how much of their derivatives and securities trading and corporate finance business US investment banks might move to continental Europe. Early estimates indicate a minimum of 20 percent. At some point, the liquidity in certain markets might move to the continent, in which case part of the trading floor will also move (OTC derivatives are a case in point; see next section).

If the US investment banks relocate part of their operations to the euro area, the ECB will become their supervisor if their assets are greater than $€ 30$ billion. While it is appropriate that a large supervisor like the ECB would be responsible, rather than smaller national supervisors, the ECB will need to beef up its markets (derivatives and securities trading and corporate finance) expertise to do the job (Danielsson, Macrae and Zigrand, 2016). 
Table 2: The UK banking system (end-2014)

\begin{tabular}{|c|c|c|}
\hline Type of Banks & $\begin{array}{c}\text { Total assets } \\
\text { (in } £ \text { billions) }\end{array}$ & $\begin{array}{c}\text { Wholesale banking } \\
\text { in London } \\
\text { (in } € \text { billions) }\end{array}$ \\
\hline $\begin{array}{c}\text { Major UK international } \\
\text { banks }\end{array}$ & $3,570(45 \%)$ & 1,180 \\
\hline Major UK domestic banks & $1,160(15 \%)$ & - \\
\hline Other UK banks & $250(3 \%)$ & 31,730 \\
\hline $\begin{array}{c}\text { Rest of the World } \\
\text { Investment Banks }\end{array}$ & $1,730(22 \%)$ & 310 \\
\hline $\begin{array}{c}\text { Rest of the World } \\
\text { Other Banks }\end{array}$ & $460(6 \%)$ & 3,750 \\
\hline Branches from EEA banks & $790(10 \%)$ & 530 \\
\hline Total UK banking system & $7,960(100 \%)$ & - \\
\hline
\end{tabular}

Source: Total assets based on Burrows and Low (2015) and for branches from EEA banks on ECB (2015). Author estimates for wholesale banking (trading and derivatives) in London.

Next, the category 'rest of the world other banks' includes subsidiaries of overseas banks operating in the United Kingdom. Many international banks, including the major European ones, also have substantial branches in London, including Deutsche Bank, BNP Paribas, Societe Generale, ING and UniCredit. Deutsche Bank with total assets of $€ 1.629$ billion receives, for example, 19 percent of its net revenues from its UK branch (Deutsche Bank, Annual Report 2015). Most of these foreign subsidiaries and branches actually do little business with UK clients. Our conservative estimate is that two thirds of their UK business is related to wholesale banking. 
Table 3: European operations of top five US investment banks: Turnover and Employees (end 2014)

\begin{tabular}{|l|c|c|}
\hline Countries & \multicolumn{2}{|c|}{ Panel A: Turnover by Country (EUR - millions ) } \\
\hline United Kingdom & 22,744 & $92 \%$ \\
\hline Germany & 513 & $2 \%$ \\
\hline France & 361 & $1 \%$ \\
\hline Italy & 193 & $1 \%$ \\
\hline Ireland & 201 & $1 \%$ \\
\hline Luxembourg & 276 & $1 \%$ \\
\hline Other EU & 438 & $2 \%$ \\
\hline Total & 24,727 & $100 \%$ \\
\hline
\end{tabular}

\begin{tabular}{|l|c|c|}
\hline Countries & \multicolumn{2}{|c|}{ Panel B: Number of Employees by Country } \\
\hline United Kingdom & 26,629 & $89 \%$ \\
\hline Germany & 794 & $3 \%$ \\
\hline France & 293 & $1 \%$ \\
\hline Italy & 326 & $1 \%$ \\
\hline Ireland & 1,011 & $3 \%$ \\
\hline Luxembourg & 491 & $2 \%$ \\
\hline Other EU & 365 & $1 \%$ \\
\hline Total & 29,909 & $100 \%$ \\
\hline
\end{tabular}

Source: Goodhart and Schoenmaker (2016)

Note: The data refer to the five US investment banks' investment banking activities in Europe. Goodhart and Schoenmaker (2016) provide a breakbown for each bank.

In sum, Table 2 estimates that close to half $(£ 3,750$ billion) of the total UK banking system is related to wholesale banking in London. In the next section, we provide a breakdown of wholesale business by category (securities and derivatives) and currency (sterling, dollar and euro).

\section{Infrastructure}

Given the amount of euro-denominated finance carried out in the UK, it is important that London, within the EEA, has direct access to the infrastructure for wholesale payments (TARGET2) and clearing (LCH-Clearnet) in euros. TARGET2, the payments system for the euro area, permits national central banks, banks and designated financial institutions within the EEA to join even if they are outside the euro area (Armstrong, 2016). UK banks and other designated financial institutions are permitted to be direct participants in TARGET2 even though the Bank of England does not participate.

Armstrong (2016) argues that if the UK were to leave the EU and not join the EEA, then banks in the UK could no longer be direct members of TARGET2. They would have to operate through subsidiaries (or perhaps branches assuming the UK is deemed 'equivalent' in terms of regulation) within the EEA. This would make euro banking via the UK more expensive. It would also erode the attraction of London as a destination for non-EEA banks to establish their EU headquarters. 
Moving to clearing, central counterparties (CCPs) are important for the settlement of securities and derivatives transactions. There are three clearing houses operating in the UK which are recognised by both the UK and the EU: CME Europe, a derivatives exchange and wholly-owned subsidiary of US-based CME group, LCH.Clearnet Group Ltd, majority owned and operated by the London Stock Exchange Group, and the London Metal Exchange Limited. Of the three clearing houses, LCH has by far the biggest share of euro-denominated clearing in the UK (Batsaikhan, 2016).

The European Central Bank initially exempted the UK entity of LCH from Target2 as part of its 'location requirement', but the Court of Justice of the EU (ECJ) subsequently decided that the ECB has no competence under the Treaty on the Functioning of the European Union (TFEU) to impose such requirements on the clearing houses. Furthermore, by imposing location requirements, the ECB violated the freedom of establishment, freedom to provide services and freedom of movement of capital in the single market (Batsaikhan, 2016; Armstrong, 2016). But outside the EEA, the UK would no longer have the protection of the TFEU and the ECJ. This is no problem for LCH.Clearnet Group itself, as it has major entities in New York, London and France (see Table 2). If needed, LCH can thus move its euro-denominated clearing business to Paris.

Table 4: LCH Clearing - overview

\begin{tabular}{|l|c|c|c|}
\hline \multicolumn{4}{|c|}{ LCH.Clearnet Group } \\
\hline Subsidiary & $\begin{array}{c}\text { LCH.Clearnet } \\
\text { Limited }\end{array}$ & LCH.Clearnet SA & LCH.Clearnet LLC \\
\hline Location & London, UK & Paris, France & New York, US \\
\hline Products & $\begin{array}{c}\text { OTC Swaps, Forex, } \\
\text { Derivatives, Equities } \\
\text { and Bonds, Repos }\end{array}$ & $\begin{array}{c}\text { Derivatives, } \\
\text { Equities and Bonds, } \\
\text { Credit default } \\
\text { swaps, Repos }\end{array}$ & OTC Swaps \\
\hline $\begin{array}{l}\text { Profit after tax } \\
\text { (mln. Euros), 2015 }\end{array}$ & 63.8 & 28.2 & 10.2 \\
\hline Headcount, 2015 & 452 & 168 & 12 \\
\hline
\end{tabular}

Source: LCH Annual Report 2015.

\section{Trading}

The final step for the assessment of the impact of Brexit on the City of London is an estimation of euro-denominated trading. At the outset, we stress that our calculations provide a preliminary assessment of the main market segments and should be interpreted with some caution. The main purpose of our preliminary calculations is to get an idea of the possible impact.

The main wholesale financial markets in London cover:

- Derivatives

- Foreign exchange trading

- Private and public bond trading

- Equity trading

- Commodities trading 
If access to euro clearing and settlement in London ceases, we expect the greatest impact to be on the bond and derivatives markets. Forex is an international market, in which London has a prime position. Settlement of FX transactions happens through CLS (originally Continous Linked Settlement), the largest multicurrency cash settlement system to mitigate settlement risk for the FX transactions of its member banks, and is thus not dependent on London's access to TARGET2. That would therefore not need to change should access to TARGET2 be stopped. Next, the settlement of equity trades is closely linked to the respective stock exchanges, on which the equity trades are executed. Finally, commodities (e.g. crude oil and metals) trading is largely a dollardenominated business.

The BIS Triennial Central Bank Survey of foreign exchange and derivatives market activity is the largest survey in its field (BIS, 2016). Table 5 provides figures for the OTC single currency interest rate derivatives, which counts for the majority (79 percent) of the global OTC derivatives market. It shows that London accounts for about 75 percent of euro-denominated trades and New York for 78 percent of the US dollar trades in 2016 (Panel B of Table 5). These large shares are no surprise, because these two markets are the most liquid interest rate derivatives markets in euros and dollars, respectively, and thus attract the majority of trading in the respective currencies. While 50 percent of the global OTC interest rate derivatives market related to euro-denominated derivatives in 2013, this position was taken over by dollar-denominated derivatives in 2016.

\section{Table 5. Global OTC single currency interest rate derivatives turnover in April 2013 and 2016, (Daily averages in millions of USD)}

\begin{tabular}{|c|c|c|c|c|c|c|c|c|c|}
\hline \multirow{2}{*}{$\begin{array}{c}\text { Panel A } \\
\text { April } \\
2013\end{array}$} & \multicolumn{2}{|c|}{ France } & \multicolumn{2}{|c|}{ Germany } & \multicolumn{2}{|c|}{ United Kingdom } & \multicolumn{2}{|c|}{ United States } & \multirow{2}{*}{$\begin{array}{c}\text { TOTAL } \\
\text { Amount }\end{array}$} \\
\hline & Amount & $\begin{array}{l}\text { Share of } \\
\text { total (\%) }\end{array}$ & Amount & $\begin{array}{l}\text { Share of } \\
\text { total (\%) }\end{array}$ & Amount & $\begin{array}{l}\text { Share of } \\
\text { total (\%) }\end{array}$ & Amount & $\begin{array}{l}\text { Share of } \\
\text { total (\%) }\end{array}$ & \\
\hline Euro & 141,245 & $10.6 \%$ & 88,125 & $6.6 \%$ & 927,840 & $69.4 \%$ & 27,090 & $2.0 \%$ & $1,336,075$ \\
\hline $\begin{array}{l}\text { Pound } \\
\text { sterling }\end{array}$ & 4,746 & $2.3 \%$ & 4,728 & $2.3 \%$ & 189,802 & $91.9 \%$ & 3,162 & $1.5 \%$ & 206,643 \\
\hline US dollar & 52,080 & $6.7 \%$ & 6,205 & $0.8 \%$ & 110,235 & $14.2 \%$ & 546,268 & $70.4 \%$ & 776,268 \\
\hline TOTAL & 202,210 & $7.3 \%$ & 101,347 & $3.7 \%$ & $1,347,749$ & $48.9 \%$ & 628,153 & $22.8 \%$ & $2,758,583$ \\
\hline
\end{tabular}

\begin{tabular}{|c|c|c|c|c|c|c|c|c|c|}
\hline \multirow{2}{*}{$\begin{array}{c}\text { Panel B } \\
\text { April } \\
2016\end{array}$} & \multicolumn{2}{|c|}{ France } & \multicolumn{2}{|c|}{ Germany } & \multicolumn{2}{|c|}{ United Kingdom } & \multicolumn{2}{|c|}{ United States } & \multirow{2}{*}{$\begin{array}{c}\text { TOTAL } \\
\text { Amount }\end{array}$} \\
\hline & Amount & $\begin{array}{l}\text { Share of } \\
\text { total (\%) }\end{array}$ & Amount & $\begin{array}{l}\text { Share of } \\
\text { total (\%) }\end{array}$ & Amount & $\begin{array}{l}\text { Share of } \\
\text { total (\%) }\end{array}$ & Amount & $\begin{array}{l}\text { Share of } \\
\text { total (\%) }\end{array}$ & \\
\hline Euro & 100,648 & $13.2 \%$ & 16,562 & $2.2 \%$ & 573,664 & $75.2 \%$ & 6,832 & $0.9 \%$ & 762,494 \\
\hline $\begin{array}{l}\text { Pound } \\
\text { sterling }\end{array}$ & 6,648 & $2.5 \%$ & 509 & $0.2 \%$ & 247,489 & $94.8 \%$ & 2,333 & $0.9 \%$ & 261,113 \\
\hline US dollar & 26,833 & $1.8 \%$ & 2,455 & $0.2 \%$ & 215,157 & $14.4 \%$ & $1,167,958$ & $78.0 \%$ & $1,497,627$ \\
\hline TOTAL & 141,215 & $4.7 \%$ & 31,311 & $1.0 \%$ & $1,180,246$ & $39.0 \%$ & $1,240,774$ & $41.0 \%$ & $3,028,031$ \\
\hline
\end{tabular}

Source: BIS Triennial Central Bank Survey of foreign exchange and derivatives markets activity (BIS, 2015 and 2016)

What do these statistics tell us? First, the City of London is currently home to the main market in euro-denominated interest rate derivatives (with 75 percent of euro- 
denominated trading). Second, the potential impact for the City of London is that up to 49 percent ( $=\$ 573.7$ billion $/ \$ 1,180.2$ billion) of its interest rate derivatives market could move to continental Europe after Brexit. Third, France is emerging as the dominant player on the continent. France improved its share of euro-denominated derivatives from 10.6 percent in 2013 to 13.2 percent in 2016, while Germany dropped from 6.6 to 2.2 percent over the same period.

Bond trading is less centralised and done through different platforms, each of which has its own clearing and settlement arrangements. Therefore, we cannot speak of a central market place(s). Nevertheless, we try to give a picture of activity using two indicators: amounts outstanding and cleared trades. Table 6 provides an overview of the amount of outstanding private debt securities in the major countries: France, Germany, the UK and the US. The amounts are broken down by type of bond (bank, other financial or corporate) and currency (euro and US dollar). The relative share of outstanding securities is a good proxy for the relative share of trading. London has a less dominant position in the private bond market than in the derivatives market. The UK market share of euro-denominated private bonds is about 16 percent, while Germany and France have 21 and 14 percent respectively. Moreover, in the corporate bond segment, Germany (27 percent) and France (22 percent) have larger market shares than the UK (11 percent).

Table 6. Private debt securities outstanding, Q1 2016 (in billion USD)

\begin{tabular}{|l|c|c|c|c|c|c|c|c|c|}
\hline & \multicolumn{2}{|c|}{ France } & \multicolumn{2}{c|}{ Germany } & \multicolumn{2}{c|}{ United Kingdom } & \multicolumn{2}{c|}{ United States } & \multicolumn{2}{c|}{ TOTAL } \\
\hline & Amount & $\begin{array}{c}\text { Share of } \\
\text { total (\%) }\end{array}$ & Amount & $\begin{array}{c}\text { Share of } \\
\text { total (\%) }\end{array}$ & Amount & $\begin{array}{c}\text { Share of } \\
\text { total (\%) }\end{array}$ & Amount & $\begin{array}{c}\text { Share of } \\
\text { total (\%) }\end{array}$ & Amount \\
\hline Euro & 2029.6 & 21.2 & 1373.1 & 14.4 & 1568.3 & 16.4 & 1084.1 & 11.3 & $\mathbf{9 5 5 5 . 2}$ \\
- banks & 900.1 & 20.3 & 368.2 & 8.3 & 795 & 17.9 & 384.6 & 8.7 & $\mathbf{4 4 3 6 . 6}$ \\
- other financials & 467.1 & 17.9 & 460.8 & 17.6 & 505.1 & 19.3 & 259.3 & 9.9 & $\mathbf{2 6 1 6 . 1}$ \\
- corporates & 662.4 & 26.5 & 544.1 & 21.7 & 268.2 & 10.7 & 440.2 & 17.6 & $\mathbf{2 5 0 2 . 5}$ \\
\hline US dollar & 614.9 & 4.3 & 934.2 & 6.5 & 1678.6 & 11.8 & 3929.1 & 27.5 & $\mathbf{1 4 2 6 7 . 2}$ \\
- banks & 225.4 & 4.5 & 386.2 & 7.8 & 821.1 & 16.5 & 720.5 & 14.5 & $\mathbf{4 9 7 3 . 4}$ \\
- other financials & 225.2 & 4.0 & 450.4 & 8.0 & 522.1 & 9.3 & 2514.9 & 44.8 & $\mathbf{5 6 1 8 . 2}$ \\
- corporates & 164.3 & 4.5 & 97.6 & 2.7 & 335.4 & 9.1 & 693.7 & 18.9 & $\mathbf{3 6 7 5 . 6}$ \\
\hline \multicolumn{1}{c|}{ TOTAL } & $\mathbf{5 2 8 9}$ & & $\mathbf{4 6 1 4 . 6}$ & & $\mathbf{6 4 9 3 . 8}$ & & $\mathbf{1 0 0 2 6 . 4}$ & & $\mathbf{4 7 6 4 4 . 8}$ \\
\hline
\end{tabular}

Source: BIS, Debt securities issues and amounts outstanding, Table C3.

Note: Amount of issue for each country is the sum of resident issuers and national issuers. Total amount is the total for all countries.

Moving to government bond trading, Figure 5 shows the monthly amount of cleared government bond trades (both cash bond and repo trades) executed by LCH.Clearnet. The UK entity clears trades for the following markets: Austrian, Belgian, Dutch, German, Irish, Finnish, Portuguese, Slovakian, Slovenian and UK government bonds. The French entity processes the cash trades and repos for Italian, French and Spanish government securities. LCH.Clearnet thus serves the major markets for euro-area government bonds. It is interesting to see that French entity has recently overtaken the UK entity, partly because of the increased trade in euro government bonds from the south of Europe. 
The trading and clearing of the bonds of the nine euro-area governments, which now done in the UK, could be easily transferred to the French entity, if the UK entity can no longer clear euro-denominated trades. Figure 5 shows that monthly government bond trading amounts to $€ 6$ trillion, both in the UK and France.

It should be noted that LCH.Clearnet shows only a partial picture of euro government bond clearing. Euroclear in Brussels and Clearstream in Frankfurt also clear a large amount of euro-area government bonds.

\section{Figure 5: Monthly amount of cleared government bond trades by LCH (in EUR billions)}

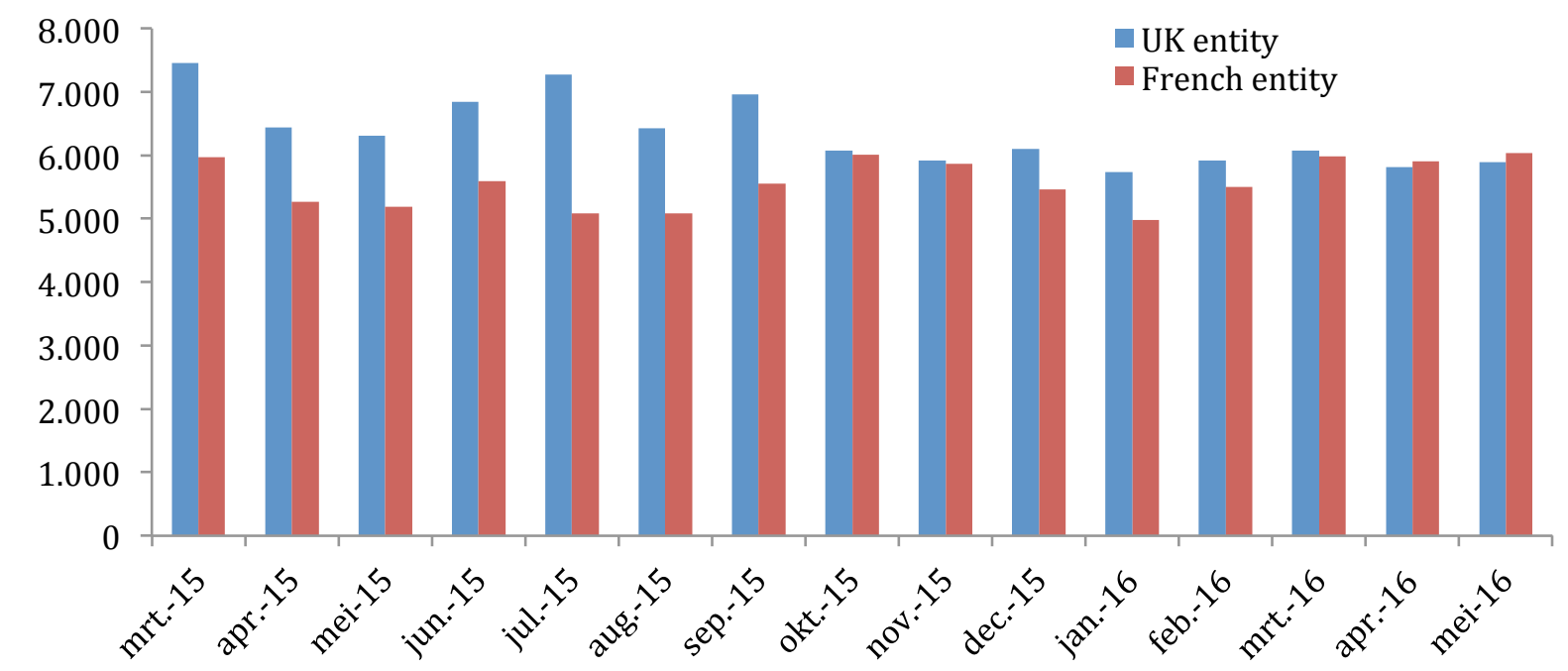

Source: LCH, http://www.lch.com/asset-classes/repoclear/volumes

In summary, the City of London has a dominant position in the euro-denominated OTC derivatives markets, which it might lose after Brexit. Its position in bond trading is more on par with France and Germany.

\section{Future relationship with the EU in financial services}

Negotiations about the future relationship between the UK and the EU have still to start at the time of writing (September 2016). Pisani-Ferry et al (2016) give an overview of the different models for market access provided by the EU to financial sectors in non-EU member states (i.e. Norway model, Switzerland model, Turkey model, Canada model, and the WTO model). A key issue is whether the UK wants to remain in the internal market. An important requirement for staying within the internal market is the acceptance of the supranational institutions (the European Commission and the European Court of Justice), which uphold the appropriate functioning of the internal market. Pisani-Ferry et al (2016) have made a proposal for a continental partnership, whereby the UK would have a say on EU policies but ultimate formal authority would remain with the EU. This partnership could keep the UK in the internal market.

If the UK were not to remain in the internal market, it would become a third country. The EU applies an equivalence regime, which allows access to an EU country from third countries if the EU (the European Commission and/or relevant supervisors) deem the supervision of the third country equivalent (Goodhart and Schoenmaker, 2016). 
Nevertheless, the relevant supervisor(s) in the EU country can still impose regulatory and supervisory requirements. Moreover, the third country licence does not provide the passport to do business across the EU.

Whatever model is chosen, there is a need for transitional arrangements to provide certainty to financial services and markets in the period between the UK's withdrawal and its future relationship with the EU (Schoenmaker, 2016). A key element in the transition is grandfather clauses and a sufficiently long grace period. Grandfathering allows a smooth transition from the old to the new regime. It means that a licence received under the old regime remains valid under the new regime (i.e. is grandfathered). Another element is the legal form of the partnership between the EU and the UK. The more this relationship is hard-wired in a Treaty, the less scope there is for changing parts of the relationship in the future. This provides more certainty for financial services providers. Nevertheless, it will be difficult to address the uncertainty on the outcome during the negotiations. A clear and joint vision on the desired outcome from the outset and a relatively speedily negotiation are helpful to keep this uncertainty to a minimum.

The UK government faces for its financial services sector a fundamental choice between global and EU business. On the one hand, London can position itself as an international financial centre with light-touch regulation and supervision to try to gain extra global business. But under that model, the equivalence of UK regulation and supervision will come under pressure, which makes access to the EU more difficult and cumbersome (extra regulatory and supervisory requirements from the EU). On the other hand, the UK can choose to remain close (i.e. equivalent) to EU legislation and thus favour its regional business in the EU. Under this model, London can still attract global business, as it does currently. 


\section{References}

Armstrong, A. (2016), 'EU membership, financial services and stability', National Institute Economic Review 236, 31-38.

Bank for International Settlements (2015), Triennial Central Bank Survey of foreign exchange and derivatives market activity in 2013, Basel.

Bank for International Settlements (2016), 2016 Triennial Central Bank Survey of Foreign Exchange and OTC Derivatives Markets, Basel.

Batsaikhan, U. (2016), Brexit and the UK's Euro-denominated market: the role of clearing houses, Blogpost, 7 June, Bruegel.

Burrows, O. and K. Low (2015), Mapping the UK financial system, Bank of England Quarterly Bulletin 2015 Q2, Bank of England.

Danielsson, Macrae, and Zigrand (2016), 'On the financial market consequences of Brexit', Voxeu, 7 June.

ECB (2015), EU Structural Financial Indicators 2014, Frankfurt.

FT (2016), François Hollande rules out City's euro clearing role, 29 June.

Goodhart, C. and D. Schoenmaker (2016), 'The Global Investment Banks are now all Becoming American: Does that Matter for Europeans?', Journal of Financial Regulation, 2, 163-181.

Haldane, A., S. Brennan and V. Madouros (2010), 'What is the contribution of the financial sector: Miracle or mirage?', in: A. Turner et al (eds), The Future of Finance: The LSE Report, London: LSE.

Pisani-Ferry, J., N. Röttgen, A. Sapir, P. Tucker and G. Wolff (2016) 'Europe after Brexit: A proposal for a continental partnership', 29 August, Brussels.

Schoenmaker, D. (2016), Written evidence for The House of Lords EU Sub-Committee on Financial Affairs chaired by Baroness Falkner of Margravine on the future of Financial Services in the UK following the vote to leave the European Union', September, Bruegel, available at

http://bruegel.org/2016/09/the-future-of-financial-services-in-the-uk-following-thebrexit-vote/

Schoenmaker, D. and J. Sass (2016), 'Cross-border Insurance in Europe: Challenges for Supervision', The Geneva Papers on Risk and Insurance, 41, 351-377.

Schoenmaker, D. and N. Véron (2016) (eds) European banking supervision: the first eighteen months, Blueprint 25, Bruegel, available at http://bruegel.org/2016/06/blueprint-european-bankingsupervisionthe-first-eighteen-months/ 